\title{
Morphology and ultrastructure of salivary glands of male treehopper Tricentrus brunneus Funkhouser (Hemiptera: Membracoidea)
}

\author{
Haiying Zhong, Yalin Zhang \& Cong Wei
}

\begin{abstract}
Zhong, H., Zhang, Y. \& Wei, C. 2015: Morphology and ultrastructure of salivary glands of male treehopper Tricentrus brunneus Funkhouser (Hemiptera: Membracoidea). — Entomol. Fennica 26: 201-212.

The salivary glands of male treehopper Tricentrus brunneus Funkhouser comprise a pair of acinous principal glands each with an anterior lobe and a posterior lobe; a pair of elbow-shaped accessory glands. Every accessory gland connects with the principal gland via a thin accessory salivary duct. The anterior lobe contains three types of acini (I, II and III), whereas the posterior lobe possesses only one type of acinus (IV). Two efferent salivary ducts fuse into a common salivary duct. Different acinis cells are filled with secretory granules that are distinct in size, number, shape and electron-density, indicating a maturation process before secreted. Infoldings in different acini suggest dilution of substances before being secreted. The presence of microvilli in acinus IV and the accessory gland duct possibly indicates the undergoing maturation of secretions. Electron-dense fine granules existed in the accessory gland cells, possibly related to virus transmission.
\end{abstract}

H. Zhong, Key Laboratory of Plant Protection Resources and Pest Management, Ministry of Education, Entomological Museum, Northwest A\&F University, Yangling, Shaanxi 712100, China; and, State Key Laboratory Breeding Base for Zhejiang Sustainable Pest and Disease Control, Institute of Plant Protection and Microbiology, Zhejiang Academy of Agricultural Sciences, Hangzhou 310021, China; E-mail: zhy8085@163.com

Y. Zhang \& C. Wei, Key Laboratory of Plant Protection Resources and Pest Management, Ministry of Education, Entomological Museum, Northwest A\&F University, Yangling, Shaanxi 712100, China

Received 5 January 2015, accepted 8 June 2015

\section{Introduction}

Treehoppers and leafhoppers (Membracoidea) are the most diverse group within Cicadomorpha (Shcherbakov 1996), with approximately 25,000 species described worldwide (Deitz \& Dietrich 1993, McKamey 1998, Dietrich et al. 2001). Treehoppers are characterized by their extremely developed and peculiar-shaped pronotum which resembles thorns, parts of plants, or other objects in their habitat. They are also best known for their special behaviors, such as parental care, antmutualism, secreting brochosomes and anointing behavior, and acoustic communication (Gouranton \& Maillet 1967, Day 1993, Wood 1993, Rakitov 1996, Cocroft et al. 2006, Morales \& Beal 2006, Zhong et al. 2011).

The phytophagous treehoppers cause damage 
not only by sucking juice from the plants, but also by ovipositing into the tissue of the hosts (Butcher 1953, Yuan \& Chou 2002, Wallace \& Deitz 2007). The most serious damage caused by treehoppers is usually through the transmission of virus or bacteria during sap sucking (Simons \& Coe 1958, Ammar \& Nault 2002, Lashomb et al. 2002, Yuan \& Chou 2002), which can cause pseudo-curly top of certain plants such as the ragweed (Ambrosia sp.), chickweed (Stellaria media (L.)), tomato (Lycopersicum esculentum (L.)), nightshade (Solanum nigrum L.), tobacco (Nicotiana glutinosa L.) and jimsonweed (Datura stramonium L.) (Simons \& Coe 1958, Simons 1962, Tsai 1989, Briddon et al. 1996).

Although the transmission of pathogens is closely related to salivary glands of some insects (Grylls et al. 1947, Conti \& Plumb 1977, Shikata 1979, Wijkamp et al. 1993, Ammar \& Nault 2002, Ammar \& Hogenhouta 2005, Froissart et al. 2010), the morphology and ultrastructure of the salivary glands of treehoppers have not been well/properly documented to date. Herein, we investigate the salivary glands of the treehopper Tricentrus brunneus Funkhouser, a widely distributed species mainly feeding on the paper mulberry (Broussonetia papyrifera (L.)), the black locust (Robinia pseudoacacia L.) and the thorny elaeagnus (Elaeagnus pungens Thunberg) in China (Yuan \& Chou 2002), using both light microscopy and transmission electron microscopy. We are aiming to provide a detailed description of the salivary glands of $T$. brunneus at both the morphological and ultrastructural levels, and to supply information for future investigation about the pathogen transmission of treehoppers.

\section{Materials and methods}

\subsection{Treehopper collection}

As the salivary glands of the adult males and females exhibit great similarity, males were used for this study. Live T. brunneus (at least 50 individuals) were collected from the plant $B$. papyrifera in Yangling, Shaanxi Province, China in August 2010 and 2012. The individuals were anesthetized by chilling before they were dissected.

\subsection{Light microscopy}

The treated individuals were dissected in a phosphate buffered saline (PBS, $0.2 \mathrm{M}, \mathrm{pH}$ 7.2) under a Stereoscopic Zoom Microscope Motic SMZ168 (Xiamen, China). Their salivary glands were dissected out and photographed by a scientific digital micrography system equipped with an Auto-Montage Imaging system and a Qimaging Retiga 2000R digital camera (QImaging, Surrey, B.C., Canada).

\subsection{Transmission electron microscopy}

The salivary glands were fixed in $2.5 \%$ glutaraldehyde in PBS (0.1 M, pH 7.2) for $12 \mathrm{~h}$ at $4{ }^{\circ} \mathrm{C}$. Before being post-fixed in $1 \%$ osmium tetroxide for $2 \mathrm{~h}$, the samples were rinsed five times $(5,10,15,20$, and 30 min, respectively) in PBS, then dehydrated in an ethanol series and $100 \%$ (v v) acetone. The materials were infiltrated by a mixture of epoxy resin (Epon 812) in acetone, and were embedded in pure Epon 812 for $24 \mathrm{~h}$ at $30^{\circ} \mathrm{C}$, then for $48 \mathrm{~h}$ at $60^{\circ} \mathrm{C}$. Ultra-thin sections were stained with uranyl acetate and lead citrate, and examined under a JEM-1230 TEM at $80 \mathrm{kV}$.

The terminology for the salivary gland structures mainly follows that of Tsai and Perrier (1996).

\section{Results}

\subsection{Morphology of the salivary glands}

The salivary glands of Tricentrus brunneus are paired structures located centrally inside the head and thorax. Each salivary organ consists of a principal gland and an accessory gland. The principal gland is acinous and contains an anterior lobe and a posterior lobe, with the former possessing three types of acini (I, II, III) but the latter having only one type of acinus (IV). The acini of types I, II and III are all one in number; while the rosetteshaped acini of type IV are six in number and are closely arranged concentrically. Two thin efferent salivary ducts fuse into a thick common salivary duct that opens into the salivary syringe. The ar- 


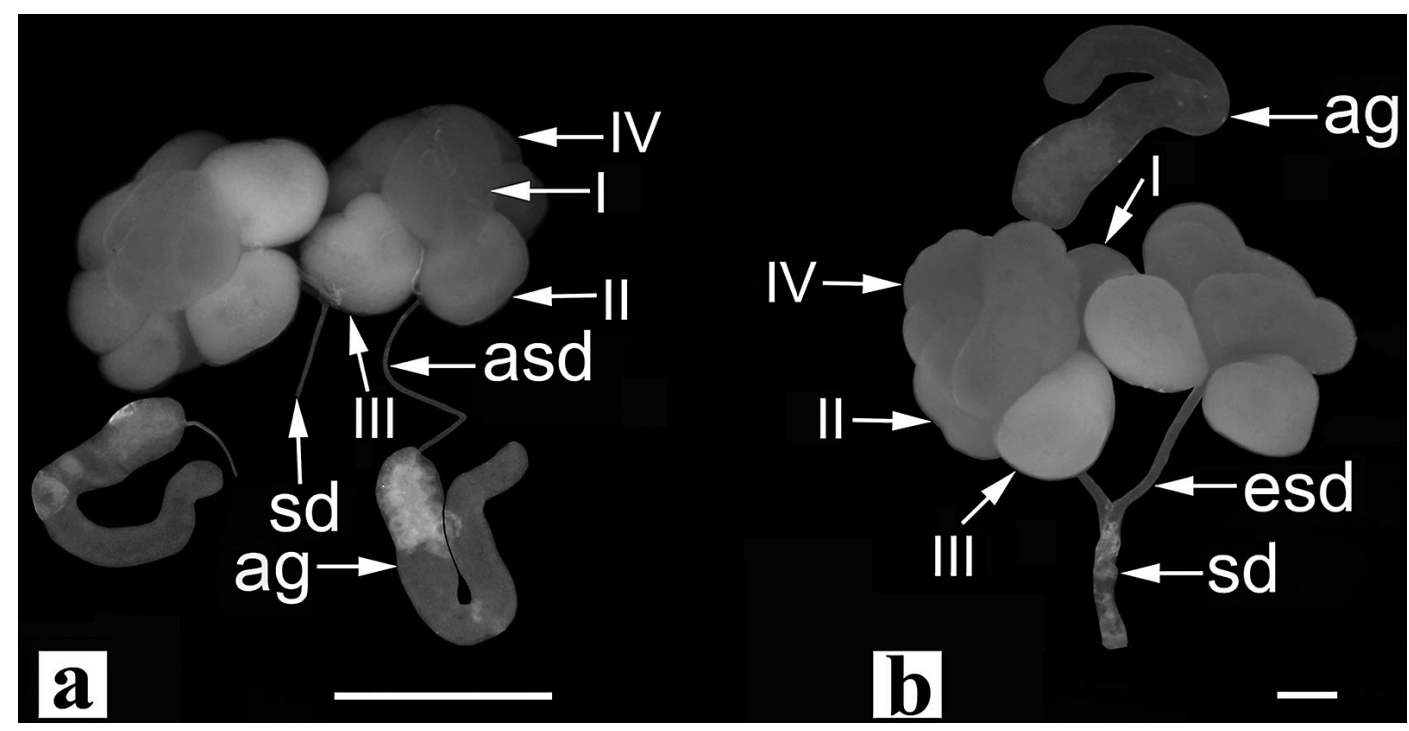

Fig. 1. Light micrographs of salivary glands of male Tricentrus brunneus. - a. Anterior view. - b. Lateral view. Abbreviations: ag, elbow-shaped accessory gland; esd, efferent salivary duct; asd, accessory salivary duct; sd, common salivary duct; I-III, three types of acini contained in anterior lobes of principal gland; IV, the fourth type of acinus of posterior lobe in principal gland. Scale bars: $0.5 \mathrm{~mm}$ in a, $0.1 \mathrm{~mm}$ in b.

rangement of the acini of the salivary gland is shown in Fig. 1. The accessory gland is elbowshaped and joins the principal gland via a thin and long accessory salivary duct.

\subsection{Ultrastructure of the salivary glands}

\subsubsection{Principal gland}

Different types of secretory cells are identified in the principal gland (acini I, II, III, IV), based on their cytoplasmic characteristics. Both the semithin section and ultrathin section of the tissue (acini I, II, III) show that their cells are composed of abundant secretory granules throughout, and are devoid of other elements such as microvilli. The acini I and II possess one type of cell. The efferent salivary duct, common duct, and accessory salivary duct exhibit a great similarity in the cell characteristics (for details, see below).

\subsubsection{Acinus I}

The basal plasma membrane of the secretory cells invaginates into developed infoldings associated with mitochondria (Fig. 2a). Scattered elements of rough endoplasmic reticulum and numerous secretory granules are observed in the cytoplasm. The secretory granules are different in number, size, shape and electron-density; of these, some are electron-dense in the center and electron-lucent at the periphery. Some secretory vesicles of irregular shape are evident around the secretory granules; inside, they appear to contain many fine granular materials.

\subsubsection{Acinus II}

Secretory cells are characterized by poorly-developed basal infoldings, abundant secretory granules and sparsely scattered secretory vesicles filled with granular material (Figs 2b, 3a, b). The secretory vesicles are large and the secretory granules are small, but both irregular in shape (Fig. 2c). Three types of secretory granules are observed in the cells, which vary in number, size, shape and electron-density: electron-dense granules without a black border; electron-dense granules with a black border; and granules with electron-dense center and electron-lucent periphery (Figs 2d, 3a). Small oval mitochondria scattered around the secretory vesicles are also found in the cytoplasm (Fig. 3b). 

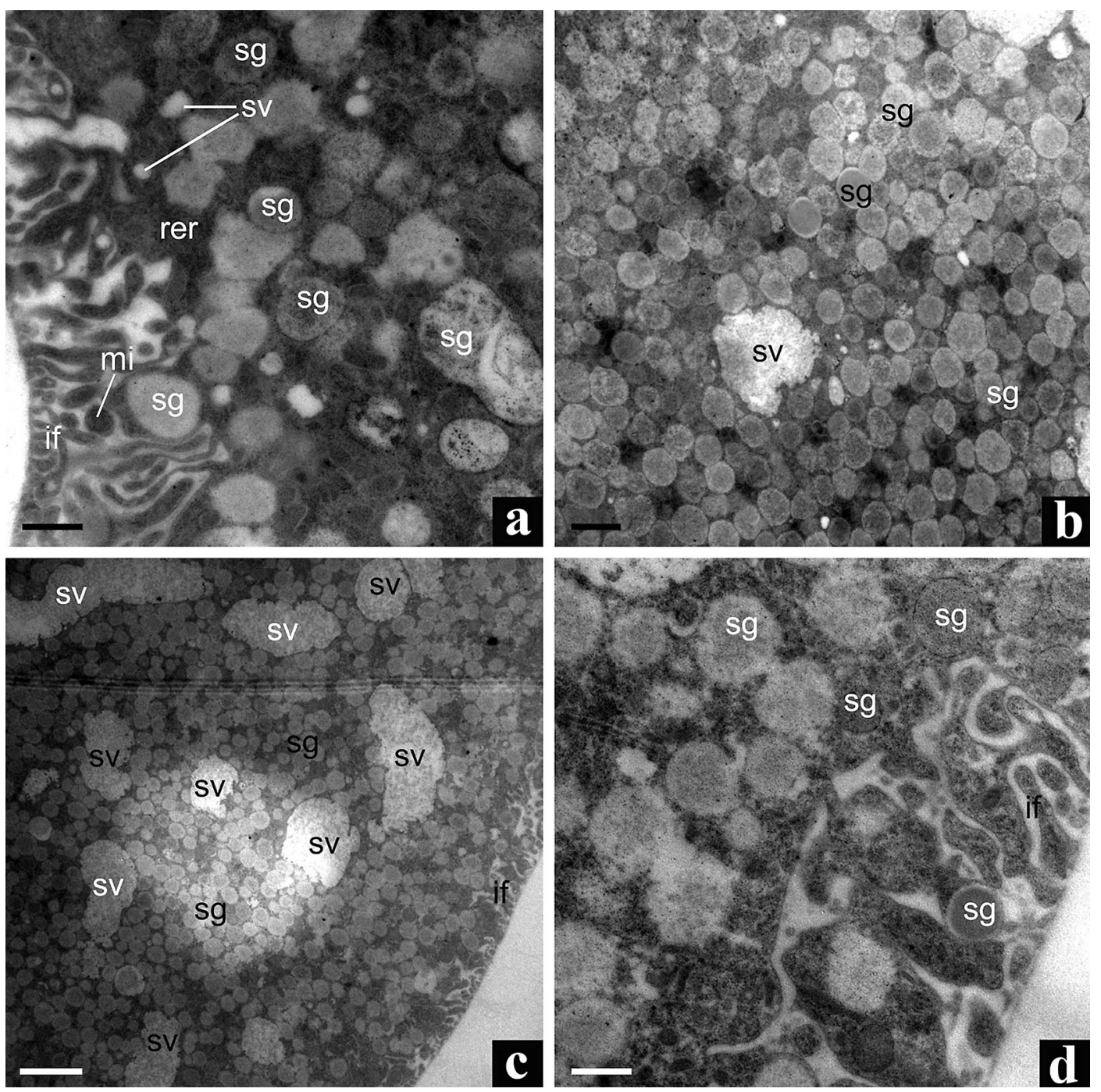

Fig. 2. Electron micrographs of acini I and II in anterior lobe of acinous principal salivary glands of male Tricentrus brunneus. - a. Peripheral part of a cell of acinus I with basal plasma membrane invaginating into infoldings. Mitochondria and rough endoplasmic reticulum scatter among secretory granules and secretory vesicles. - b. Cytoplasm of a cell of acinus II with abundant secretory granules filling cytoplasm. Secretory vesicles among secretory granules. - c. Peripheral portion of cells in acinus II with basal infoldings, secretory granules and secretory vesicles. $-d$. Peripheral portion of a cell in acinus II. Cytoplasm contains secretory granules. Abbreviations: if, infoldings; mi, mitochondria; rer, rough endoplasmic reticulum; sg, secretory granules; sv, secretory vesicles. Scale bars: $1.0 \mu \mathrm{m}$ in a and d, $2.0 \mu \mathrm{m}$ in b, $5.0 \mu \mathrm{m}$ in c.

\subsubsection{Acinus III}

The cells are remarkably featured by large areas of rough endoplasmic reticulum and numerous electron-dense secretory granules. The secretory granules are rounded and vary in size. Some oval secretory vesicles are scattered among the secretory granules.
The secretory vesicles in the acini III cells are regular in shape and very small in size. Infoldings of the basal plasma membrane are poorly-developed (Fig. 3c, d).

\subsubsection{Acinus $I V$}

Cells of the acinus IV undergoing different pro- 

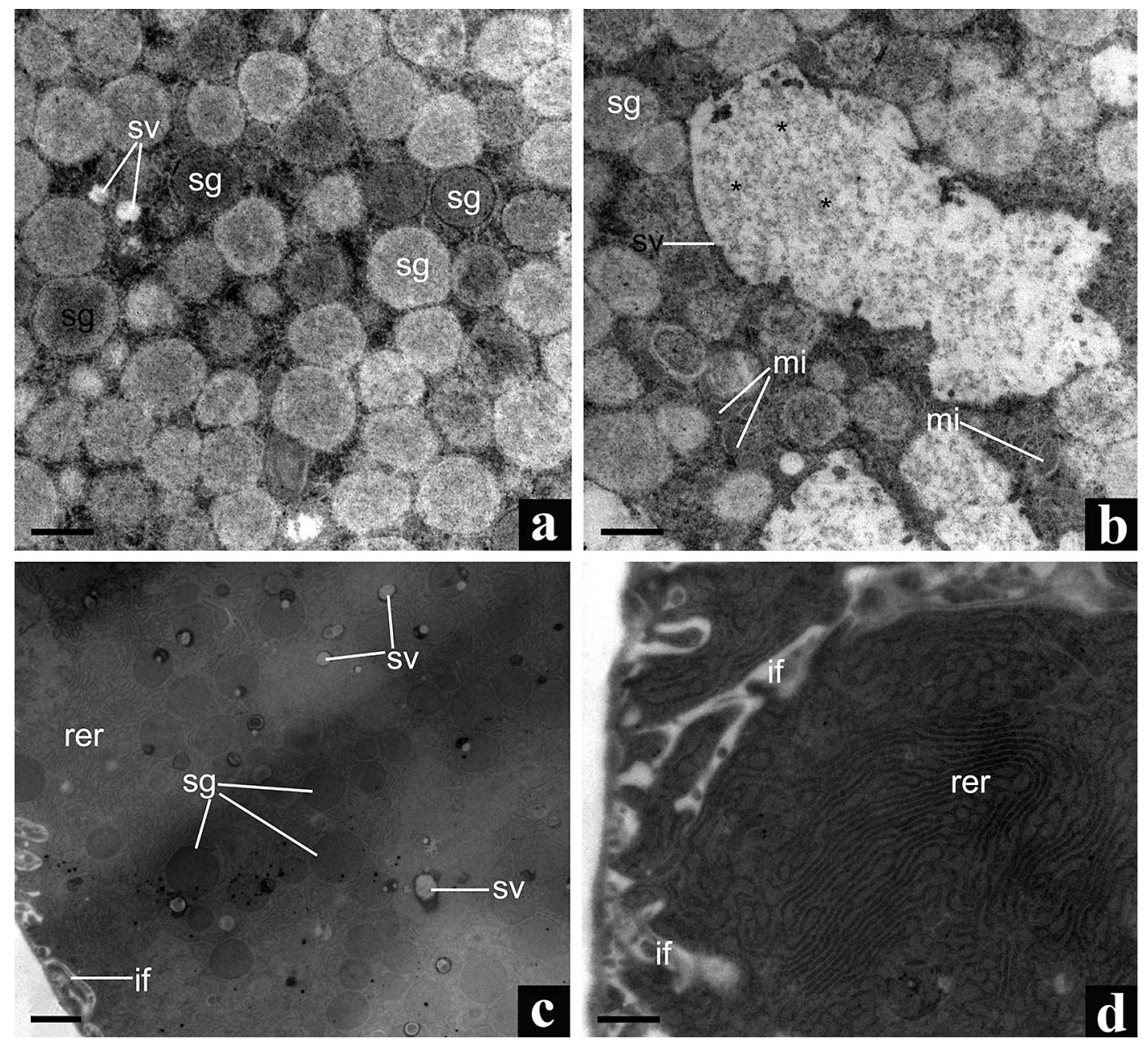

Fig. 3. Electron micrographs of acini II and III in anterior lobe of acinous principal salivary glands of male Tricentrus brunneus. - a. Cytoplasm of acinus II contains numerous secretory granules, with some granules having a black border. - b. Cytoplasm of acinus II contains mitochondria and large secretory vesicles with fine granular material (asterisks). - c. Peripheral portion of a cell of acinus III with many secretory granules, extensive rough endoplasmic reticulum and very shallow, poorly-developed basal infoldings. - d. Peripheral part of cell of acinus III with large area of rough endoplasmic reticulum and basal infoldings. Abbreviations: if, infoldings; mi, mitochondria; rer, rough endoplasmic reticulum; sg, secretory granules; sv, secretory vesicles. Scale bars: $1.0 \mu \mathrm{m}$ in a, b and $\mathrm{d}, 2.0 \mu \mathrm{m}$ in $\mathrm{c}$.

cesses of the physiological development are recognized, with one characterized by peculiar secretory granules and wide basal infoldings associated with mitochondria. In the first process of the physiological development, secretory granules are prominent, around which there are some irregular-shaped secretory vesicles (Fig. 4a). These secretory granules vary in size and electron-density, and possess a black border (Fig. 4b).

In the second process of the physiological development, the basal plasma membrane invagi- nates into wide infoldings containing elongated mitochondria (Figs 4c, d). In the cytoplasm, three types of secretory granules with different number, size and electron-density are observed: electron-dense granules with an apparent black border; granules with an electron-dense center and an electron-lucent periphery; and large electronlucent granules (Fig. 4d). Some small and electron-dense granules appear to fuse into larger electron-lucent granules (Fig. 5a).

In the third process of the physiological de- 

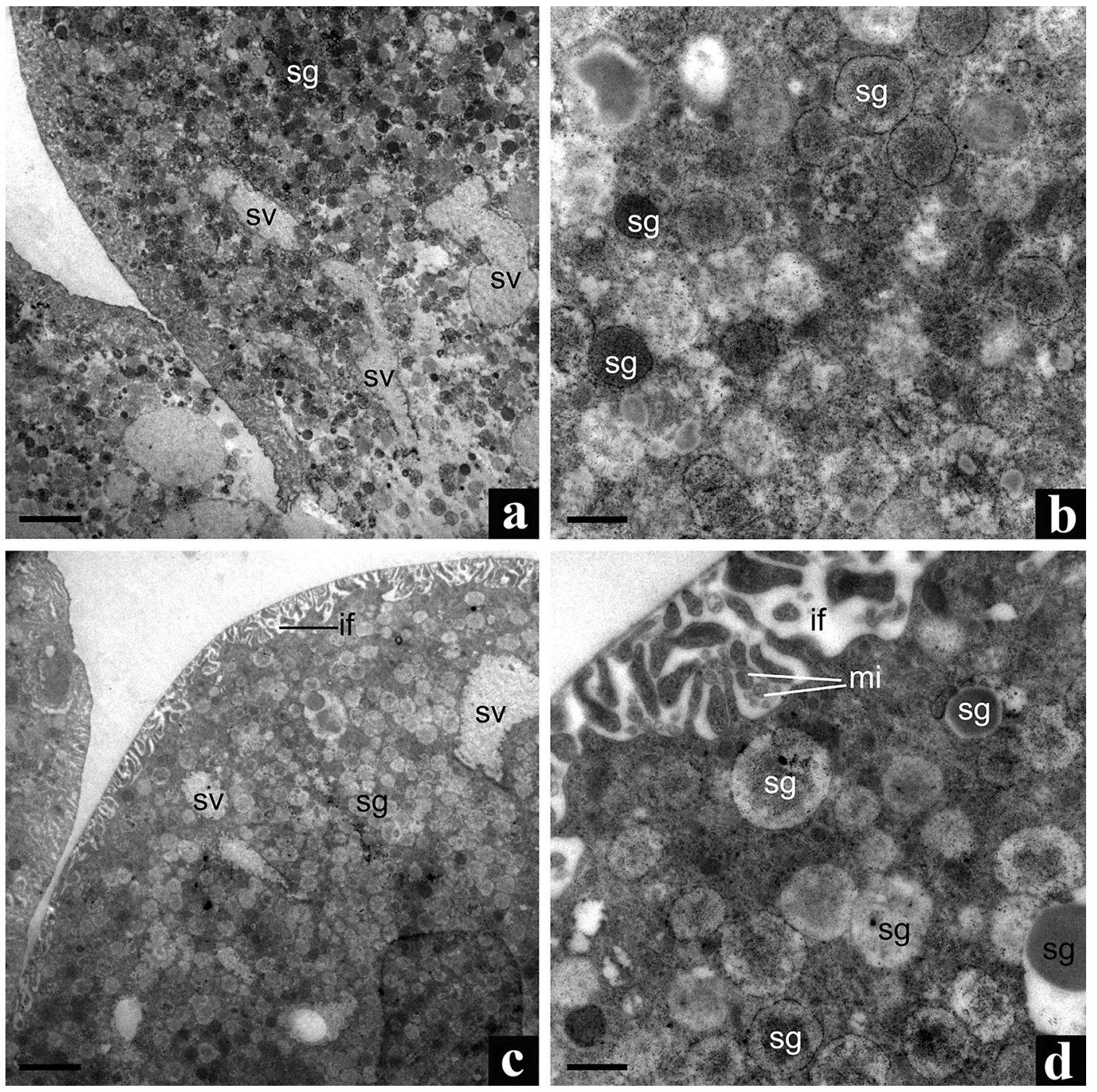

Fig. 4. Electron micrographs of acinus IV in posterior lobe of acinous principal salivary glands of male Tricentrus brunneus. - a. Peripheral part of a cell in the first process of the physiological development. Cytoplasm contains abundant secretory granules and secretory vesicles. - b. Cytoplasm of a cell undergoing the first process of the physiological development possesses border-black secretory granules of different electron-density. - c. Peripheral part of a cell in the second process of the physiological development, showing numerous secretory granules, interspersed with secretory vesicles. Basal infoldings are wide. $-d$. Peripheral portion of a cell in the second process of the physiological development possesses basal plasma membrane invaginating into wide infoldings associated with mitochondria. Many secretory granules of different size and electron-density exist near infoldings. Abbreviations: if, infoldings; mi, mitochondria; sg, secretory granules; sv, secretory vesicles. Scale bars: $5.0 \mu \mathrm{m}$ in a and d, $1.0 \mu \mathrm{m}$ in $\mathrm{b}, 5.0 \mu \mathrm{m}$ in $\mathrm{c}$.

velopment, the basal plasma membrane invaginates deeply and forms infoldings that are regular (Fig. 5b). Such cell shows electron-lucent secretory granules filled with abundant fine granular materials (Fig. 5a, d). Mitochondria and intracellular canaliculi coated with short microvilli facing the lumen are found among the secretory granules (Fig. 5b). A large amount of fine granular materials fill the lumen of the intracellular canaliculi (Fig. 5b). Inside the lumen of some intracellular canaliculi, a cloud of myelin figure is also observed (Fig. 5d). Large nuclei with evident 

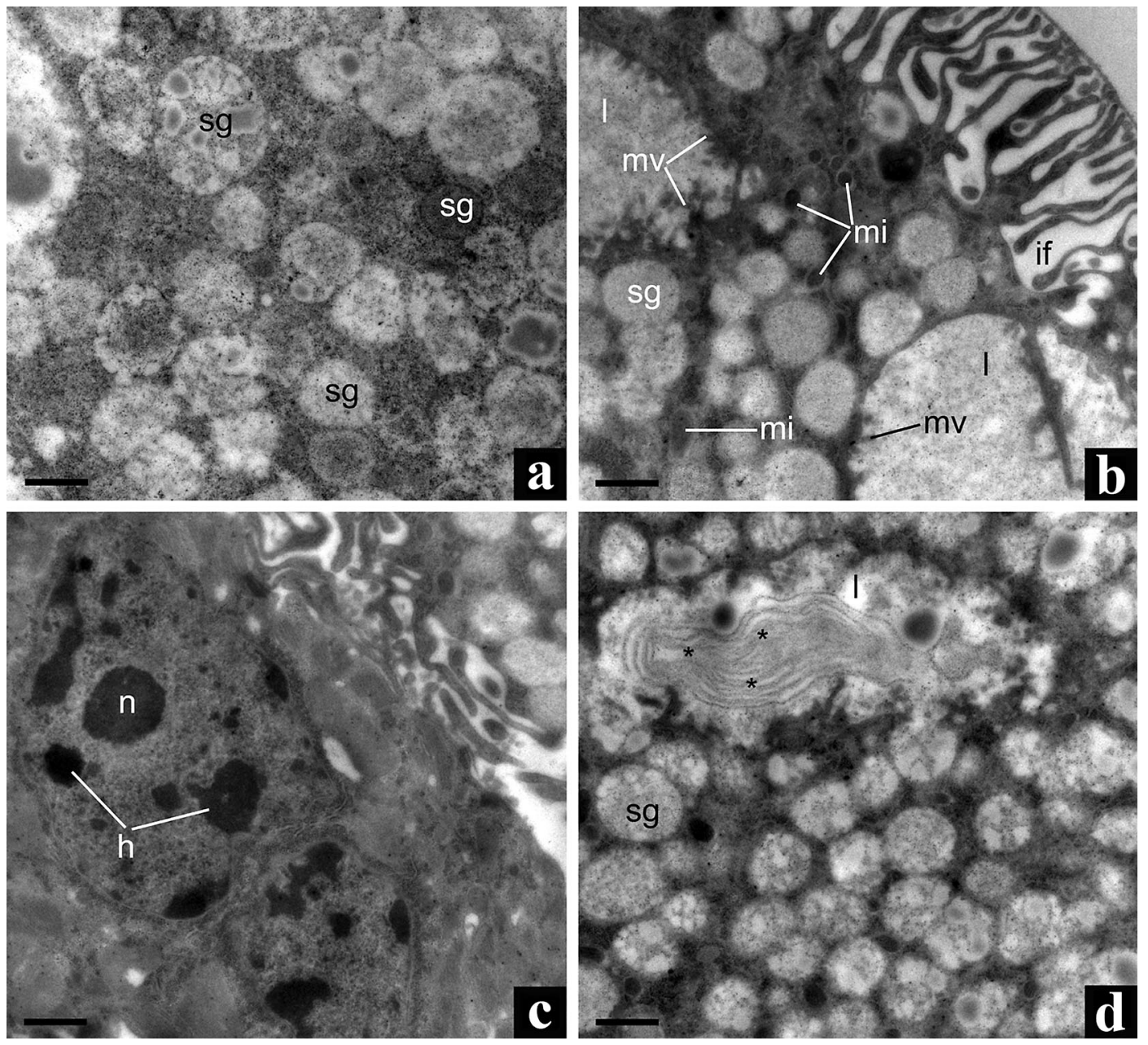

Fig. 5. Electron micrographs of acini IV in posterior lobe of acinous principal salivary glands of male Tricentrus brunneus. - a. Cytoplasm of cells in the second process of the physiological development contains abundant secretory granules varying in electron-density. $-b$. Peripheral part of cells in the third process of the physiological development, showing abundant electron-lucent secretory granules and well-developed basal infoldings. Intercellular channels is lined with short and sparse microvilli. Cytoplasm also contains many mitochondria. $-\mathrm{c}$. Cytoplasm of cells in the third process of the physiological development, showing large nucleus with clumps of heterochromatin (h). $-\mathrm{d}$. Cytoplasm of cells in the third process of the physiological development, showing fine granular materials contained in numerous electron-lucent secretory granules. Lumen of intercellular channels possessing myelin figure (asterisks). Abbreviations: if, infoldings; mi, mitochondria; rer, rough endoplasmic reticulum; sg, secretory granules; sv, secretory vesicles; I, lumen; mv, microvilli; n, nucleus. Scale bars: $1.0 \mu \mathrm{m}$ in a-d.

nucleoli and small clumps of heterochromatin are also present in the cytoplasm (Fig. 5c).

In the fourth process of the physiological development, infoldings of the basal plasma membrane are poorly-developed, and have a very shallow profile (Fig. 6a). This cell is featured by abundant electron-dense secretory granules and a large area of rough endoplasmic reticulum (Fig. $6 \mathrm{~b} c)$. The secretory granules vary in shape and size, with some smaller granules appearing to fuse into larger ones. Very small secretory vesicles also exist near the rough endoplasmic reticulum that extends to the basal infoldings (Fig. 6d).

\subsubsection{Accessory gland}

In the cells of the accessory gland and the accessory salivary duct, the basal infoldings are not ob- 

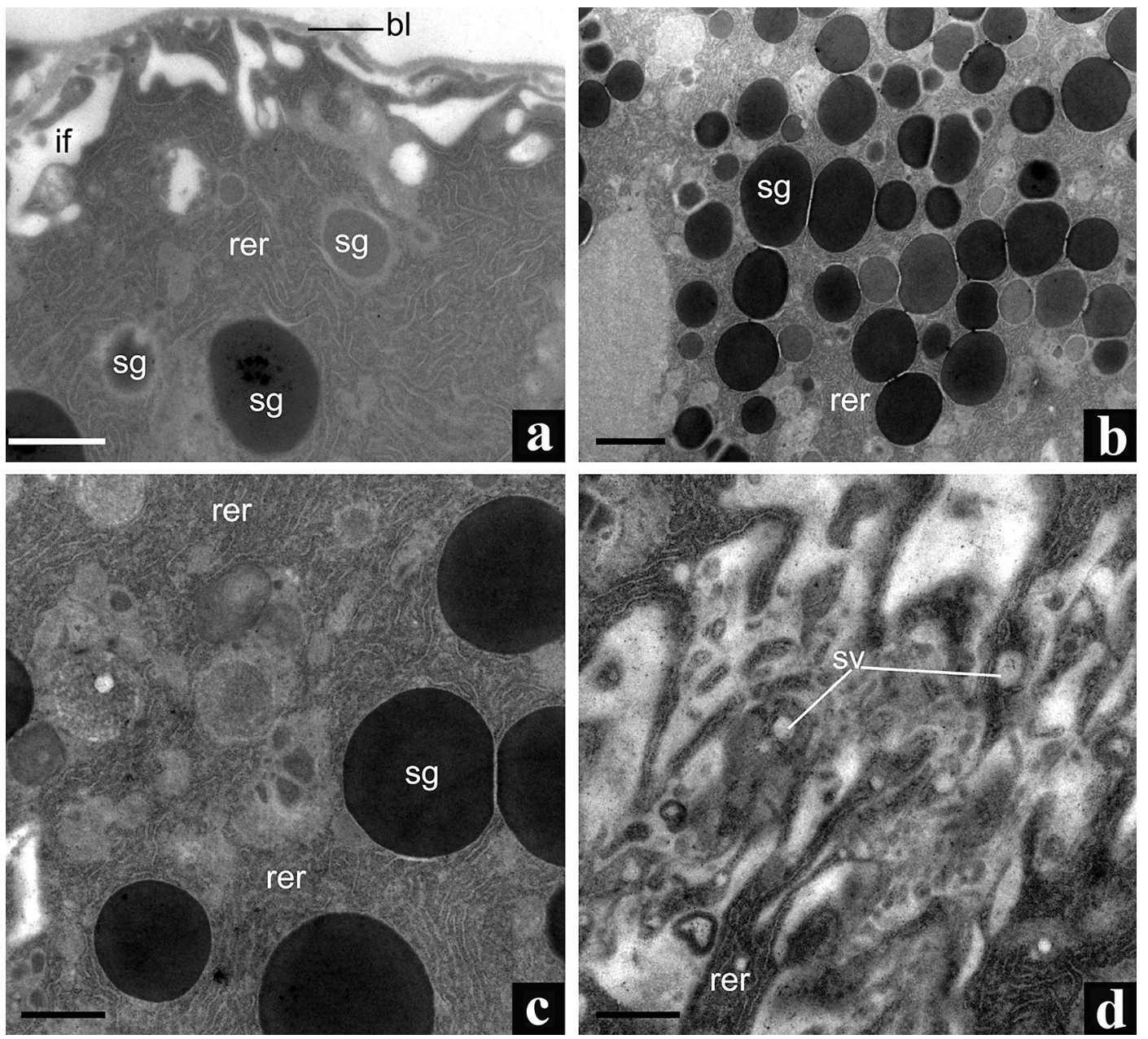

Fig. 6. Electron micrographs of acini IV in posterior lobe of acinous principal salivary glands of male Tricentrus brunneus. $-a$. Peripheral part of cells in the fourth process of the physiological development contains basal infoldings, secretory granules and extensive rough endoplasmic reticulum. - b. Cytoplasm undergoing the fourth process of the physiological development shows abundant secretory granules of different electron-density and size. Extensive rough endoplasmic reticulum exists among secretory granules. $-c$. Cytoplasm of cells in the fourth process of the physiological development has electron-dense secretory granules and rough endoplasmic reticulum. - d. Rough endoplasmic reticulum of cells in the fourth process of the physiological development extends into basal plasma membrane invaginations. Some small secretory vesicles exist adjacent to rough endoplasmic reticulum. Abbreviations: if, infoldings; rer, rough endoplasmic reticulum; sg, secretory granules; sv, secretory vesicles; bl, basal lamina. Scale bars: $1.0 \mu \mathrm{m}$ in a, c and d, $2.0 \mu \mathrm{m}$ in b.

served, but other organelles exhibit some differences.

Cells of the accessory gland contain secretory vesicles, oval nuclei, and electron-dense fine granules (less than $0.3 \mu \mathrm{m}$ in diameter) (Fig. 7a). Scattered elements of rough endoplasmic reticulum are observed among the granules (Fig. 7b). Microtubules and myelin figure are also visible in the cytoplasm (Fig. 7c). Cells of the accessory salivary duct are characterized by a thick basal lamina and developed microvilli at the apical border. In the cytoplasm, abundant oval mitochondria, spherical electron-dense granules, and large nuclei with nucleoli and clumps of heterochromatin are observed (Fig. 7d). 

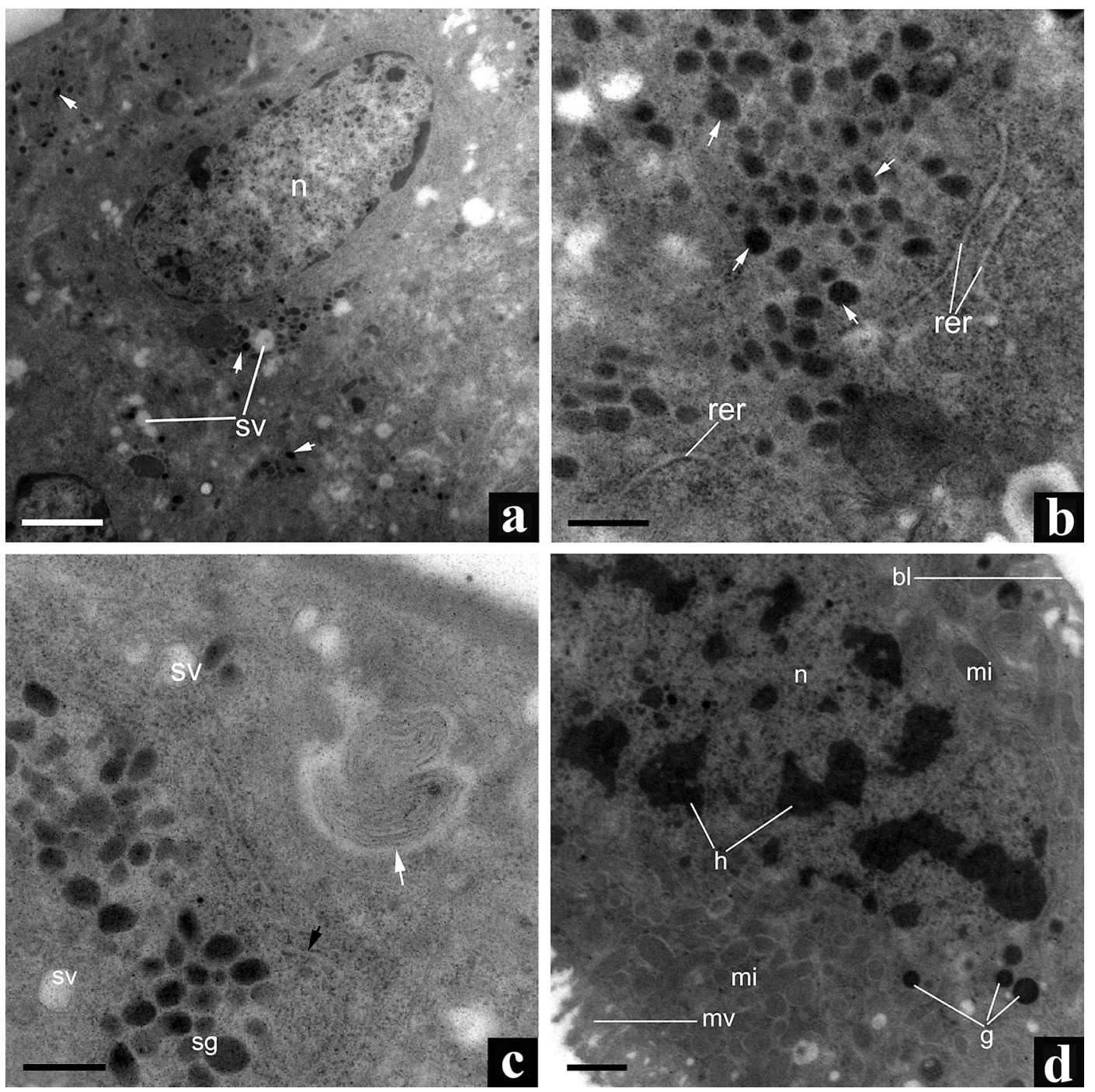

Fig. 7. Electron micrographs of cells of accessory gland and accessory salivary duct. - a. Peripheral part of a cell of accessory gland with ovoid nuclei, small electron-lucent secretory vesicles and fine electron-dense granules (white arrows). - b. Fine electron-dense granules (white arrows) and rough endoplasmic reticulum in accessory gland cells. - c. Microtubules (black arrows) and myelin figure (white arrow) in accessory gland cells. - d. Several mitochondria, electron-dense granules and large nuclei with clumps of heterochromatin in cytoplasm of accessory salivary duct. Apical border of cells is densely packed with microvilli. Basal lamina is thick. Abbreviations: mi, mitochondria; rer, rough endoplasmic reticulum; sv, secretory vesicles; sg, secretory granules; mv, microvilli; $\mathrm{n}$, nucleus; bl, basal lamina; g, electron-dense granules; h, clumps of heterochromatin. Scale bars: $2.0 \mu \mathrm{m}$ in a, $0.5 \mu \mathrm{m}$ in $\mathrm{b}$ and $\mathrm{c}, 1.0 \mu \mathrm{m}$ in $\mathrm{d}$.

\section{Discussion}

Morphologically, the salivary glands of T. brunneus are similar to those found in some leafhoppers (Dobroscky 1931, Berlin \& Hibbs 1963, Gil-Fernandez \& Black 1965, Nasu 1965, Sogawa 1965, Tsai \& Perrier 1996, Wayadande et al.
1997). However, each type of acinus of the anterior lobe in T. brunneus is only one in number, which is much less than that described in Cicadellidae. The differences among the salivary glands might be a characteristic of different families within Membracoidea.

Basal infoldings and apical microvilli greatly 
increase the effective surface area of cells, and effectively enhance the exchange and transport of substances (O'Donnell \& Maddrell 1983). The infoldings can increase the area for transport of water from the hemolymph to the cells, thus changing the concentration of saliva (Serrão \& Cruz-Landim 1996, 2000, Abdalla \& CruzLandim 2005, Serrão et al. 2008). The existence of infoldings in cells of different acini of $T$. brunneus suggests that the dense secretions are diluted to facilitate saliva secretion into the efferent salivary duct. Microvilli play a vital role in the reabsorption of water, electrolytes, and other components of initial secretion (Nunes \& Camargo-Mathias 2006). The presence of microvilli in acinus IV and the accessory gland duct of the salivary glands of $T$. brunneus probably indicate that the secretions in these organs are undergoing maturation before being discharged.

The presence of large areas of rough endoplasmic reticulum in the cells of the principal gland of T. brunneus indicates proteinaceous granules may be produced there. This is consistent with the suggestion that the principal gland plays an important part in the synthesis of protein (Baptist 1941, Miles 1960, 1972, Reis et al. 2003, Swart \& Felgenhauer 2003, Swart et al. 2006, Azevedo et al. 2007). However, existence of scattered elements of rough endoplasmic reticulum and lack of basal infoldings in the cells of the accessory gland of $T$. brunneus might indicate the secretions produced by the accessory gland are watery and possess a few enzymes, as has been suggested by Ponsen (1972).

Secretory granules of different size, morphology and electron-densities are observed in the same type of cells and/or different type of cells of the principal gland in T. brunneus, suggesting that substances of different nature might be synthesized, or that the synthesized materials experience a maturation process, as has been indicated for the salivary glands of Peregrinus maidis (Ashmead) by Ammar (1986) and Mahanarva fimbriolata (Stål) by Nunes \& Camargo-Mathias (2006). Electron-dense fine granules being different from the above mentioned secretory granules are found in the cells of the accessory gland of T. brunneus. Virus-like granules and viruses such as luteoviruses and the pea enation mosaic enamovirus (PEMV) closely associated with the accessory gland (especially with the anterior portion of the gland) have been observed in the cells of the accessory gland of aphids, such as the Myzus persicae (Sulzer) (Gildow et al. 1997, Gildow 1999). Therefore, the fine granules present in the cells of the accessory gland of $T$. brunneus are probably related to virus transmission. However, their nature and function need to be investigated further.

In conclusion, the ultrastructural characters indicate the salivary glands of T. brunneus have the following functions: (1) the principal gland is able to produce concentrated or stocked proteinrich secretions, which have to be diluted before discharge into the efferent salivary duct; (2) cells of the accessory gland may be closely related to the transmission of virus or bacteria; and (3) secretory cells synthesize and secrete the saliva containing enzymes and other substances.

Acknowledgements. We sincerely thank two anonymous reviewers for their critical review and providing valuable comments to this manuscript. This study is supported by the Program for New Century Excellent Talents in Universities (NCET-10-0691).

\section{References}

Abdalla, F. C. \& Cruz-Landim, C. 2005: Ocorrência, morfologia e ultra-estrutura da glândula de Dufour de Scaptotrigona postica Latreille (Hymenoptera, Meliponini). - Neotropical Entomology 34: 47-57. [In Portuguese, English abstract.]

Ammar, E. D. 1986: Ultrastructure of the salivary glands of the planthopper Peregrinus maidis (Ashmead) (Homoptera: Delphacidae). - International Journal of Insect Morphology and Embryology 15: 417-428.

Ammar, E. D. \& Nault, L. R. 2002: Virus transmission by leafhoppers, planthoppers and treehoppers (Auchenorrhyncha, Homoptera). - Advances in Botanical Research 36: 141-167.

Ammar, E. \& Hogenhouta, S. 2005: Use of immunofluorescence confocal laser scanning microscopy to study distribution of the bacterium corn stunt spiroplasma in vector leafhoppers (Hemiptera: Cicadellidae) and in host plants. - Annals of the Entomological Society of America 98: 820-826.

Azevedo, D. O., Serrão, J. E., Zanuncio, J. C., Zanuncio, J. S., Martins, G. F., Marques-Silva, S. \& Sossai, M. F. 2007: Biochemical and morphological aspects of salivary glands of the predator Brontocoris tabidus (Heteroptera: Pentatomidae). — Brazilian Archives of Biology and Technology 50: 469-477. 
Baptist, B. A. 1941: The morphology and physiology of the salivary glands of Hemiptera-Heteroptera. Quarterly Journal of Microscopical Science 82: 91139.

Berlin, L. C. \& Hibbs, E. T. 1963: Digestive system morphology and salivary enzymes of the potato leafhopper, Empoasca fabae (Harris). - Iowa Academy of Sciences 70: 527-540.

Briddon, R. W., Bedford, I. D., Tsai, J. H. \& Markham, P. G. 1996: Analysis of the nucleotide sequence of the treehopper-transmitted geminivirus, tomato pseudocurly top virus, suggests a recombinant origin. - Virology 219: 387-394.

Butcher, F. G. 1953: Unusual abundance of the treehopper Umbonia crassicornis A. \& S. - Florida Entomologist 36: 57-59.

Cocroft, R. B., Shugart, H. J., Konrad, K. T. \& Tibbs, K. 2006: Variation in plant substrates and its consequences for insect vibrational communication. - Ethology 112: 779-789.

Conti, M. \& Plumb, R. T. 1977: Barley yellow striate mosaic virus in the salivary glands of its planthopper vector Laodelphax striatellus Fallén. - Journal of General Virology 34: 107-114.

Day, M. F. 1993: Brochosomes of Australian Cicadelloidea. - In: Drosopoulos S., Petrakis P. V., Claridge M. F. \& de Vrijer P. W. F. (eds): Proceedings of the 8th Auchenorrhyncha Congress, Greece, 9-13, Delphi, 110 pp.

Deitz, L. L. \& Dietrich, C. H. 1993: Superfamily Membracoidea (Homoptera: Auchenorrhyncha). I. Introduction and revised classification with new family-group taxa. - Systematic Entomology 18: 287-296.

Dietrich, C. H., Rakitov, R. A., Holmes, J. L. \& Black, W. C. I. V. 2001: Phylogeny of the major lineages of Membracoidea (Insecta: Hemiptera: Cicadomorpha) based on 28S rDNA sequences. - Molecular Phylogenetics and Evolution 18: 293-305.

Dobroscky, I. D. 1931: Morphological and cytological studies on the salivary glands and the alimentary tract of Cicadula sexnotata (Fallen), the carrier of aster yellow virus. - Boyce Thompson Institute 3: 39-58.

Froissart, R., Doumayrou, J., Vuillaume, F., Alizon, S. \& Michalakis, Y. 2010: The virulence-transmission trade-off in vector-borne plant viruses: a review of (non)existing studies. - Philosophical Transactions of the Royal Society 365: 1907-1918.

Gildow, F. E., Reavy, B., Mayo, M. A., Woodford, T. \& Duncan, G. H. 1997: Potato leafroll virus-like particles lacking readthrough protein are transmitted by Myzus persicae. - Phytopathology 87: 33.

Gildow, F. E. 1999: Luteovirus transmission and mechanisms regulating vector-specificity. - In: Smith H. G. \& Barker H. (eds): The Luteoviridae: 88-113. Wallingford, Centre for Agriculture and Biosciences International, $297 \mathrm{pp}$.

Gil-Fernandez, C. \& Black, L. M. 1965: Some aspects of the internal anatomy of the leafhopper Agallia constricta (Homoptera: Cicadellidae). - Annals of the Entomological Society of America 58: 275-284.
Gouranton, J. \& Maillet, P. L. 1967: Origine et structure des brochosomes. - Journal of Microscopy 6: 53-64.

Grylls, N. E., Waterford, C. J., Filshie, B. K. \& Beaton, C. D. 1947: Electron microscopy of rugose leaf curl virus in red clover, Trifolium pratense and in the leafhopper vector Austroagallia torrida. - Journal of General Virology 23: 179-183.

Lashomb, J., Iskra, A., Gould, A. B. \& Hamilton, G. 2002: Bacterial leaf scorch of amenity trees: a wide-spread problem of economic significance to the urban forest. - USDA Forest Service NA-TP-01-03.

Mckamey, S. H. 1998: Taxonomic catalogue of the Membracoidea (exclusive of leafhoppers): second supplement to fascicle 1, Membracidae of the general catalogue of Hemiptera. - Memoirs of the American Entomological Institute 60: 1-377.

Miles, P. W. 1960: The salivary secretions of a plant-sucking bug, Oncopeltus fasciatus (Dall.) (Heteroptera: Lygaeidae). III. Origins in the salivary glands. - Journal of Insect Physiology 4: 271-282.

Miles, P. W. 1972: The saliva of Hemiptera. — Advances in Insect Physiology 9: 183-255.

Morales, M. A. \& Beal, L. H. 2006: Effects of host plant quality and ant tending for treehopper Publilia conca$v a$. - Annals of the Entomological Society of America 99: 545-552.

Nasu, S. 1965: Electron microscopic studies on transovarial passage of rice dwarf virus. - Japanese Journal of Applied Entomology and Zoology 9: 225-237.

Nunes, P. H. \& Camargo-Mathias, M. I. 2006: Ultrastructural study of the salivary glands of the sugarcane spittlebug Mahanarva fimbriolata (Stål, 1854) (Euhemiptera: Cercopidae). — Micron 37: 57-66.

O’donnell, M. J. \& Maddrell, S. H. 1983: Paracellular and transcellular routes for water and solute movements across insect epithelia. - Journal of Experimental Biology 106: 231-253.

Ponsen, M. B. 1972: The site of potato leafroll virus multiplication in its vector, Myzus persicae: an anatomical study. - Landbouwhogesch, Wageningen. 147 pp.

Rakitov, R. A. 1996: Post-moulting behaviour associated with Malpighian tubule secretions in leafhoppers and treehoppers (Homoptera: Membracoidea). - European Journal of Entomology 93: 167-184.

Reis, M. M., Meirelles, R. M. S. \& Soares, M. J. 2003: Fine structure of the salivary glands of Triatoma infestans (Hemiptera: Reduviidae). — Tissue and Cell 35: 393400.

Serrão, J. E., Cruz-Landim, C., 1996: A comparative study of digestive cells in different midgut regions of stingless bees (Hymenoptera: Apidae: Meliponinae). Journal of Advanced Zoology 17: 1-6.

Serrão, J. E. \& Cruz-Landim, C. 2000: Ultrastructure of the midgut epithelium of Meliponinae larvae with different developmental stages and diets. - Journal of Apicultural Research 39: 9-17.

Serrão, J. E., Castrillon, M. I., Santos-Mallet, J. R., Zanuncio, J. C. \& Gonçalves, T. C. M. 2008: Ultrastructure of the Salivary Glands in Cimex hemipterus (Hemipte- 
ra: Cimicidae). — Journal of Medical Entomology 45: 991-999.

Shcherbakov, D. E. 1996: Origin and evolution of the Auchenorrhyncha as shown by the fossil record. - In: Schaefer, C. W. (ed.): Studies on Hemipteran Phylogeny: 31-45. Entomological Society of America, Lanham, Maryland. $244 \mathrm{pp}$.

Shikata, E. 1979: Cytopathological changes in leafhopper vectors of plant viruses. - In: Maramorosch, K. \& Harris, K. F. (eds): Leafhopper vectors and plant disease agents: 309-325. Academic Press, New York. 654 pp.

Simons, J. N. \& Coe, D. M. 1958: Transmission of pseudocurly top virus in Florida by a treehopper. - Virology 6:43-48.

Simons, J. N. 1962: The pseudo-curly top disease in South Florida. - Journal of Economic Entomology 55: 358 363.

Sogawa, K. 1965: Studies on the salivary glands of rice plant leafhoppers. I. Morphology and Histology. Japanese Journal of Applied Entomology and Zoology 19: 275-290.

Swart, C. C. \& Felgenhauer, B. E. 2003: Structure and function of the mouthparts and salivary gland complex of the giant waterbug, Belostoma lutarium (Stål) (Hemiptera: Belostomatidae). - Annals of the Entomological Society of America 96: 870-882.

Swart, C. C., Deaton, L. E. \& Felgenhauer, B. E. 2006: The salivary gland and salivary enzymes of the giant waterbugs (Heteroptera; Belostomatidae). - Comparative Biochemistry and Physiology 145: 114-122.

Tsai, J. H. 1989: Biology and ecology of treehopper transmission of a geminivirus. VI. "Proceedings of the $6^{\text {th }}$ International Conference on Comparative and Applied Virology". Banff, Alberta. Symposium Abstract, W7-3.

Tsai, J. H. \& Perrier, J. L. 1996: Morphology of the digestive and reproductive systems of Dalbulus maidis and Graminella nigrifrons (Homoptera: Cicadellidae). Florida Entomologist 79: 563-578.

Wallace, M. S. \& Deitz, L. L. 2007: Treehoppers. — In: Lamp W. O., Berberet R., Higley L. \& Baird C. (eds): Handbook of Forage and Rangeland Insects: 106-108. Entomological Society of America. $180 \mathrm{pp}$.

Wayadande, A. C., Baker, G. R. \& Fletcher, J. 1997: Comparative ultrastructure of the salivary glands of two phytopathogen vectors, the beet leafhopper, Circulifer tenellus (Baker), and the corn leafhopper, Dalbulus maidis Delong and Wolcott (Homoptera: Cicadellidae). - International Journal of Insect Morphology and Embryology 26: 113-120.

Wijkamp, I., van Lent, J., Kormelink, R., Goldbach, R. \& Peters, D. 1993: Multiplication of tomato spotted wilt virus in its insect vector, Frankliniella occidentalis. Journal of General Virology 74: 341-349.

Wood, T. K. 1993: Diversity in the new world Membracidae. - Annual Review of Entomology 38: 409-435.

Yuan, F. \& Chou, I. 2002: Fauna Sinica, Insecta, Homoptera, Membracoidea, Aetalionidae Membracidae. Science Press, Beijing, China. 385 pp.

Zhong, H., Huo, W., Wei, C. \& Zhang, Y. 2011: Ultrastructure of integumental brochosomes, the secretory products of Malpighian tubules in representatives of Membracoidea (Hemiptera: Cicadomorpha) from China. - Entomotaxonomia 33: 202-212. [In Chinese, English abstract.] 